Book Review

\title{
Bolaños, Paolo A., On Affirmation and Becoming: A Deleuzian Introduction to Nietzsche's Ethics and Ontology. ${ }^{1}$
}

Jovito V. Cariño

$\mathrm{I}$

read Paolo Bolaños' maiden major work, On Affirmation and Becoming: A Deleuzian Introduction to Nietzsche's Ethics and Ontology with the felicity and pride shared by the rest of the UST Department of Philosophy for his singular feat of breaking through the world of foreign book publication. Fathering a book is no mean accomplishment and finding a foreigner for a mate adds to an already exceptional endeavor an extra layer of fulfillment. Bolaños' achievement came at the heels of the department's major publication hauls starting from Moses Angeles' God Beyond Metaphysics in 2012, Jove Jim Aguas' Person, Action and Love in 2014, and early this year, Robert Montaña's Thomistic Ethics. We have yet to add to this list titles penned by the other members of the department, which will be soon off the press either this year or the next. Worthy of note as well is the recent CHED elevation to an A2 status of Kritike, the department's official online journal, which is also under the editorship of Bolaños himself. All these undertakings are clear testament that research is alive in the Department of Philosophy and that there is more to it than the petri dish and microscope.

Bolaños' first book, I should say, is a highly textual and an equally highly textured piece. By using the description textual, I am referring to the prodigious amount of research underlying the groundwork of his work. Its size in fact can be deceiving. We have always been warned against judging a book by its cover. The same caution is useful in reading Bolaños; one definitely should be careful not to be taken in by the appearance of its handy size. The book in fact packs a punch and is doubtless equal to the task of propounding the "greatest weight" that Nietzsche spoke of when he described the immanence of eternal recurrence.

Nietzsche is an extremely popular thinker and against his wishes, he has become a fashionable philosophical figure, so fashionable that he has

${ }^{1}$ Newcastle: Cambridge Scholars Publishing, 2014. 109 pp.

(c) 2015 Jovito V. Cariño

http://www.kritike.org/journal/issue 17/carino december2015.pdf

ISSN 1908-7330

(cc) BY-NC-ND 
been a constant favorite for name-dropping even by those who can hardly spell his name let alone read him. Bolaños, however, is not addressing his book to this crowd but to scholars who thought they've got Nietzsche all figured out or whose interpretations have brought Nietzsche too far afield from the testimonies of his texts. At the outset, one might be tempted to view Bolaños' project as a mere updating or rehabilitation of Nietzsche. This manner of reading however runs counter to Bolaños' intentions and can only be supposed by someone who reads him or Nietzsche erroneously.

Of course, misreading is a possibility which Nietzsche shares with practically all philosophers especially those of the same celebrated status as his. The task of a scholar, however, as Bolaños knows fully well, is not to insulate the kernel ideas of this philosopher but to expose them to critical engagement. Thus, when I noted earlier that Bolaños' work is highly textual, I had in mind his exceptional textual ability, that is, his intimate knowledge of the lay of the land. His keen and synthetic perception allowed him to move with dexterity in and out, up and down, back and front Nietzsche's texts. Rather than taking the route of conventional exegesis, the kind that treats text as sacrosanct and immovable, Bolaños adopted Deleuze's rhizomic hermeneutics or what he called "creative experimentation," so as to activate, following Delueze's lead "the potentialities of the text and the creativity of the reader." The result of this Nietzsche-Deleuze fusion is a veritable philosophical anthropology, which in true Nietzschean fashion is both timely and untimely. That Nietzsche's philosophy can evince a philosophical anthropology is no longer a secret to the well-read, Nietzscheans and nonNietzscheans alike. But those who have yet to see Nietzsche beyond his Godis-dead pronouncement may find in Bolaños' work a pleasant surprise that will cast Nietzsche, his vocabulary and the grammar of his philosophical project in a different light, unless of course they have made up their minds that Nietzsche indeed is the anti-Christ. This explains my earlier description of the book as textured. By textured I mean nuanced, intense, daring, and cognizant of the complexity of the matter without getting mired in its complications. As pointed out earlier, Bolaños made this possible by grafting Nietzsche on Gilles Deleuze's philosophy of immanence and difference. His is a book that reads Nietzsche through the eyes of Deleuze and vice versa. Readers, therefore, are in for a double treat when they begin digging in between the book's slim covers; on one hand they get a re-education on Nietzsche and on the other, they acquire an introduction on Deleuze. While the language and style of writing of the two philosophers, being both edgy and uncompromising, can sometimes intimidate many, the efforts to linger and to pierce through the layers of their stylistic expressions will not certainly go unrewarded. Besides, readers can find relief in Bolaños' fluid prose. Lucidity of thought and writing style are a rare combination among doers of 
philosophy. To the readers' advantage, this is a gift that Bolaños generously dispensed in his book, page after page. His way with words helps cushion the impact of a dizzying encounter with concepts and notions, which though garbed in English remain as foreign and cryptic. It should be noted though that the idea to juxtapose Nietzsche with Deleuze is not Bolaños' own. The origin of such project was no less than Deleuze himself who, in his work Nietzsche and Philosophy, attempted to re-appropriate Nietzsche via his philosophy of immanence and difference. What is it in Nietzsche that requires re-statement? What more prestige or new intensity can a thinker like Deleuze add to his long-established legacy? Deleuze offered his answer to these questions in another work authored with Felix Guattari, What is Philosophy? Quoting Nietzsche himself, Deleuze wrote: “'[Philosophers] must no longer accept concepts as a gift, nor merely purify and polish them, but first make and create them, present them and make them convincing. Hitherto one has generally trusted one's concepts as if they were a wonderful dowry from some sort of wonderland,' but trust must be replaced by distrust, and philosophers must distrust most those concepts they did not create themselves." Further in the book, Deleuze punctuated this point more pointedly when he said: "What is the best way to follow the great philosophers? Is it to repeat what they said or to do what they did, that is, create concepts for problems that necessarily change?"

In engaging Nietzsche, therefore, Deleuze certainly was not offering himself merely as his mouthpiece but, as indicated earlier, as an exponent of creative experimentation that can bring Nietzschean discourse beyond the nostalgia of hermeneutics or the pessimism of deconstruction. More important than the concepts' definition, for Deleuze, is their function. The creative experimentation he was proposing, as noted by Bolaños, was meant to make "Nietzsche's ideas work. Nietzsche's ideas become alive because they are put to use, thus restoring their very philosophic dignity."

Bolaños' work is evidently suffused with the same philosophic anima. He too believes in the creative possibilities of reading and the functional potentials of the text. But in toeing the same Deleuzean line, he also runs the risk of being read as merely doing the repetition of the same or performing an exercise of eternal recurrence. Bolaños was aware of this pitfall; hence, at the very outset, he recognized his conceptual debt to Deleuze as he delineated the main premise of his book, that is, Nietzsche's critique of nihilism. His project he said was in no way an attempt to replicate what Deleuze did for Nietzsche nor did it aspire to map out the philosophic nexus between the two. "On Affirmation and Becoming," the ethics and ontology of Nietzsche interpreted via Deleuze, speaks of a much more modest promise even if the term "modest" might not accurately represent the amount of difficulty required by writing a book, specifically, writing a book with the

(c) 2015 Jovito V. Cariño http://www.kritike.org/journal/issue 17/carino december2015.pdf ISSN 1908-7330

(c) BY-NC-ND 
aforementioned theme. Bolaños' work makes for a compelling read precisely because the culture of nihilism which Nietzsche himself has sought to overcome remains as pervasive and as rampant to this day. It has undermined our institutions, damaged our cultures, divided our families and blurred our own appreciation of our humanity. One knows the clutches of nihilism remain upon us because God has died a thousand deaths in our hands and we continue to have the gall to call ourselves godly. Is ethics then possible without religion? Can we affirm our humanity and become humane without invoking transcendence or eternal values? This is a problem that haunted philosophers like Nietzsche and Deleuze all the way back to Plato as he articulated the same question in his dialogue Euthyphro. Bolaños' answer to this dilemma is a resounding yes. His concluding admonition is a clarion call for us to think differently or at least to consider anew whether or not we are ascending or descending in our becoming human. But given the textured character of his work, I take his position not as an outright exclusion of religion from human affairs but an emphatic affirmation of the inherent value of our humanity and an honest indignation against a reactive mode of thinking that constantly pulls us away from fulfilling our best potentials. In a county like our own, where life is a daily struggle against the pernicious outcomes of eternal recurrence-the same cycle of mediocrity, the same oppressive politics and policies, the same mindless politicians and policymakers-Bolaños' book could definitely be a timely and untimely intervention. The constancy of nihilistic state of things and the therapy provided by philosophy that Bolaños articulated in his book are actually the best arguments why there should be more philosophy in the university as there should be more philosophical researches. For while it is debatable whether or not philosophy can the change the world, it surely has the power to move and sway the minds of those who can. Theirs is the will-to-power that will make the difference.

Department of Philosophy, University of Santo Tomas, Philippines

(C) 2015 Jovito V. Cariño

http://www.kritike.org/journal/issue 17/carino december2015.pdf

ISSN 1908-7330

(c) BY-NC-ND 